\title{
An Exploration of Strategies for Facilitating Graduates' Transition to the World of Work: A Case of Technical, Vocational Education and Training Graduates in Uganda
}

\author{
Denis Kintu ${ }^{1,}$, Kisilu Mashtakh Kitainge ${ }^{2}$, Ahmed Ferej ${ }^{2}$ \\ ${ }^{1}$ Department of Mechanical and Production Engineering, Kyambogo University, Kampala, Uganda \\ ${ }^{2}$ Department of Technology Education, University of Eldoret, Eldoret City, Kenya
}

Email address:

dkintu@kyu.ac.ug (D. Kintu)

${ }^{*}$ Corresponding author

\section{To cite this article:}

Denis Kintu, Kisilu Mashtakh Kitainge, Ahmed Ferej. An Exploration of Strategies for Facilitating Graduates' Transition to the World of Work: A Case of Technical, Vocational Education and Training Graduates in Uganda. International Journal of Vocational Education and Training Research. Vol. 5, No. 1, 2019, pp. 1-9. doi: 10.11648/j.ijvetr.20190501.11

Received: January 18, 2019; Accepted: February 20, 2019; Published: March 14, 2019

\begin{abstract}
The major role of Technical, Vocational Education and Training (TVET) is to equip young persons with skills for the world of work. However, studies have shown that TVET graduates in Uganda experience difficulty in their transition to the world of work, implying major labor market entry problems. The study, we set out to identify different strategies for facilitating TVET graduates' transition to the world of work in Uganda. A qualitative approach was used to collect data, analyze and present findings. Thirty respondents, comprising of employers of TVET graduates, trainers and officials from: skilling Uganda, Uganda employers' union, Ministry of education officials, and TVET graduates in formal employment were randomly selected and interviewed. The various strategies identified were: use of employment agencies, income generating units at the institutions, institutional-industrial linkages, provision of start-up capital, tools and materials for self-employment, training with production and internship/ industrial attachments programs. It is recommended that an active labour market information system be established at TVET institutions to analyze, collect, evaluate and provide labour market information to identify evolving occupations, skills shortages and areas of skills oversupply and redundancy; that there should be an increase in apprenticeship programs and that TVET institutions adopt approaches such as case studies, project-based learning, real life problem-based learning, and teamwork learning activities.
\end{abstract}

Keywords: Graduates' Transition, World of Work, Technical, Vocational Education and Training

\section{Introduction}

\subsection{School-to-Work Transition}

There is increased pressure on graduates to successfully manage their transition from school to the world of work due to the changing nature of work. Graduates have to manage their own career paths in flexible and creative ways, this implies that school-to-work transition programs should be designed to assist the graduates with skills and knowledge to prepare them to enter the world of work [1]. The evolving world of work requires enhanced skill sets and areas of expertise because individuals are no longer able to look to their employing organizations to help define their career paths, nor can they expect to be with one organization for a large part of their career [2]. The graduates entering the world of work should have good expertise in their area of work; have ability to work with latest technologies; be able to work with interdisciplinary and cross-functional teams to analytically think and solve problems; and have high quality communication skills, flexibility, and emotional intelligence [3].

The transition from student life to the world of professional work is often thought of as the next big challenge for undergraduate students. University education is generally perceived as a key factor in providing graduates with the skills to make them "employable" and enable them to contribute to the nation's workforce, improve productivity 
and create economic opportunities [4]. Youth need to be prepared to take advantage of potential opportunities and to create opportunities on their own through self-employment and entrepreneurial activities. Preparation for employment starts with basic good-quality education, which provides the foundation for future human capital accumulation and the later acquisition of vocational skills in schools, training institutes, and the workplace [5]. According to an Education For All (EFA) global monitoring report of 2012, many young people face a difficult transition from school to work. The disadvantage that youth often experience in the labour market is reflected in both a lack of jobs and the low quality of jobsincluding insecure, low paid work. Factors linked to disadvantage in education, such as poverty, gender and disability, are often also associated with disadvantage in the labour market. This is not a coincidence-unequal skills development, social norms and labour market discrimination combine to lead to this outcome [6].

In an effort to facilitate school-to-work transition in China, the ministry of education in 2006 issued a guideline titled 'some suggestions on enhancing the teaching quality of vocational colleges to enhance the quality of higher vocational education'. The guideline emphasized that the knowledge and skills taught in schools should have a close relationship with the requirements of real work. Taskoriented teaching and project-based teaching were thus introduced to enhance students' competencies. The policy also required students to intern in enterprises for a period of at least half a year [7].

According to the World Bank, Africans who transition from school to work experience very long periods of inactivity, implying significant labor market entry problems. Transitions to working life for Africa's youth review revealed that in 8 countries (Cameroon, Ethiopia, The Gambia, Kenya, Malawi, Mozambique, São Tomé and Principe, and Zambia), young people face about five years of inactivity before finding work; youth in Uganda are inactive for more than three years on average. The transition duration is just one year in Côte d'Ivoire and almost seven years in Mozambique. These large differences indicate that the vulnerability of young people to unsuccessful transition varies greatly across countries [8].

The Organization for Economic Co-operation and Development (OECD) noted that globally, nearly all vocational systems suffer, to varying degrees, from inadequate partnership with labour market actors - employers and unions. This leaves vocational systems less equipped to respond to the requirements of employers and less able to transition young people into good jobs by equipping them with relevant skills. One of the ways to ease school-to-work transition is through workplace-school collaborations [9]. TVET centers and industry must work together for trainees to gain real work experience, become efficient workers, and expand employment opportunities and their network [10]. However, the link between TVET colleges and industry has not been well established in a way that allows trainees to develop their competencies. Many countries in sub-Saharan
Africa have weak industry-school relationships [11]. In his research about technical institute graduates practical skills acquisition in the upper east region of Ghana, Dasmani noted that the relationship between technical institutions and industry is not strong enough. As a result, practical skills taught do not directly fit the needs of the world of work thus fewer opportunities for employment [12].

\subsection{Technical, Vocational Education and Training (TVET) in Uganda}

In Uganda, Technical, Vocational Education and Training (TVET), includes Business education hence it is known as Business, Technical, Vocational Education and Training (BTVET). The most significant legal instrument guiding the policy formulation and reforms for this education sector is the BTVET act of 2008. The act provides that the objective of BTVET is to provide relevant and quality knowledge, values and skills for purposes of academic progression and employment in the labour market to the larger number of persons in an affordable way, and to improve the productivity capabilities of the individuals and enhance employability [13].

The BTVET system comprises- public; private; and firm based training. There are 144 public institutions; about 600 private training service providers and an unknown number of apprenticeships and enterprise based training programmes operating in Uganda. The national vision is to develop a BTVET system that will enable greater access, and realization of the full potential of Uganda's human resources. For the benefit of the economy, BTVET is capable of producing a competent and polyvalent workforce with practical work skills, entrepreneurship skills and orientation that are essential for employment [14]. Over the last five years, all BTVET institutions have experienced increases in students' enrolment and the demand is continuing to rise. The demand for employment oriented skills training will therefore continue to raise both in the medium term and in the long run. In the light of all the above realities, BTVET needs appropriate recognition and support so that it can have a significant impact on poverty eradication within the context of the pro-poor economic growth strategy [15]. Realizing the importance of TVET in facilitating skills development for the socio-economic and technological development, the Ugandan government has been at the forefront in advocating for reforms in the BTVET education subsector. A 10-year BTVET strategic plan 2011-2020, launched in October 2012 and titled 'Skilling Uganda', emphasizes a more comprehensive system of skills development to raise the quality and economic relevance of BTVET. The strategic plan targets to reform the way BTVET programmes are delivered to different groups so as to improve the competences of graduates and make them competitive and easily transition to the labour market [14].

\subsection{Statement of the Problem}

Several studies in Uganda have showed that most 
graduates from TVET training institutions find difficulty in their transition to the world of work, yet opportunities do exist in the labour market [15-19]. In almost all African countries, large numbers of graduates coming out of school system are unemployed, although opportunities for skilled workers do exist in their economy [20]. For this study, the lingering question was, "What strategies can be used to facilitate graduates' transition to the world of work in Uganda?" The study was therefore conducted to address that question.

\section{Theoretical Framework}

The study was grounded on the self-concept theory of career development as coined by Super. The theory posits that that career choice and development is essentially a process of developing and implementing a person's selfconcept. The 'self-concept' is a mix of intricate connections among a number of factors, which include physical and mental growth, personal experiences, and environmental features and stimulation [21]. However, self-concept is not necessarily a static entity. The concept involves one to evolve as he/she encounters new experiences and progresses through the developmental stages [22].

According to Rogers and Creed, career development theory 'offers a practical model for understanding how adolescents move from school to work, from career exploration to occupational establishment, and from adolescence to adulthood by emphasizing vocational development tasks and coping behaviours'. The career development theory identifies developmentally appropriate tasks and interventions at different educational levels and focuses on self-knowledge, occupational information, decision making, planning and problem solving through four intervention methods. These four intervention methods are career orientation, teaching skills for planning and exploring career possibilities, coaching of career management techniques, and role rehearsal of job problems. Coaching in career management techniques is vital for students to learn coping behaviours to deal with co-workers as well as give practical knowledge about acclimatizing to the different beliefs of the work environment [1]. They further summarized the intervention strategies from the career development theory approach to include:

a. encouragement of career orientation to increase awareness,

b. fostering of positive attitudes toward planning and exploring career development tasks,

c. teaching planning skills,

d. teaching career exploration skills,

e. coaching career management techniques, and

f. teaching problem-solving situations through role rehearsal.

\section{Literature Review}

Several studies have been conducted about School-to-work transitions of graduates.

In Australia, Rogers and Creed examined school-to-work transitions. They noted that "whereas school-to-work transition programs are typically designed to assist with this process by providing young people with skills and knowledge to prepare them to enter the world of work, the school-to-work movement has been criticized for its lack of a theoretical basis to guide these efforts to increase the vocational opportunities of young people" [1].

In Canada, Duchscher researched about the transition shock for newly graduated registered nurses. The aim was to offer a theoretical base which would assist managers, educators and seasoned practitioners to support and facilitate this professional adjustment appropriately. She concluded that it is important to bridge undergraduate educational curricula with escalating workplace expectations. The goal of such knowledge is the successful integration of new nursing professionals into the stressful and highly dynamic context of professional practice [23].

A study about factors influencing work readiness of graduates was done using a sample of 183 participants drawn from two African universities (Makerere University and the University of Venda). The aim was to explore the relationships between emotional intelligence (EI), psychological capital (PsyCap), sense of coherence (SOC) and the work readiness (WR) of graduates. Multiple regression analysis was undertaken to determine whether the independent variables (EI, SOC and PsyCap) contribute to WR. She concluded that EI and PsyCap contribute to WR, more specifically to organizational acumen and work competence [24].

A study about the effectiveness of final-year learning experiences from the perception of recent graduates at five Australian universities (Griffith University, Macquarie University, Queensland University of Technology, University of Newcastle and University of Wollongong) was done. The aim was to improve undergraduate curriculum to facilitate the transition to professional employment. Four hundred and twelve alumni from five universities completed the survey. The results indicated that graduates value case studies, group work and oral presentations, and that graduates rate lectures and guest lectures from practitioners as the least important in their transition to work. The results validate the use of graduate capability frameworks and mapping the development of the skills over the curriculum [25].

According to Quintini and Manfredi, countries with regulated labour markets and strong apprenticeship systems, such as Germany, about $80 \%$ of school leavers succeed in integrating into the labour market, a marked contrast to countries without strong work-based training systems [26]. Work-based learning is not only a powerful tool for developing both hard and soft skills and transitioning students into employment, it is also key to engaging employers and linking the mix of provision to employer needs. It is too often neglected, partly because education and training organizations find it easier to work on their own without having to involve employers, and partly because 
employers do not recognize the potential returns from offering work placements to students [27].

In his briefing paper regarding transitions from higher education to work, Harvey, Locke and Morey pointed out that;

"The relationship between graduate, institution and employer is not simple. It depends on the way in which graduates have engaged with employability development opportunities provided by institutions, be they central support services, experiences embedded in the curriculum, work experience or opportunities to reflect on and record experience. The pedagogical processes and reflection on and articulation of learning are essential elements that are mediated by subject discipline and external factors, not least the extra-curricular experience of graduates and, ultimately, the recruitment practices of employers" [28].

\section{Methodology}

The study adopted a descriptive survey design because it is used to describe the state of affairs, as it exists. It is used when collecting information about people's attitudes, opinions, habits or any of the variety of education or social issues [29]. Many educational study approaches are descriptive because they describe the conditions or existing relationships and practices that are happening [30]. The target population comprised of employers of TVET graduates, trainers, and officials from: skilling Uganda, Uganda employers' union, Ministry of education officials from BTVET department, and TVET graduates in formal employment. In total, 30 respondents were randomly selected and interviewed. The interview guides used were first tested for validity and reliability. The researchers distributed them amongst 15 senior members of staff from technical teacher education department and vocational education faculty at Kyambogo University. The items in the interview guides were found to be valid and reliable. The next step was to get permission to carry out the research in Uganda. The procedure involved submitting the research proposal to an ethical review committee. Mbarara University of Science and Technology Research Ethical Committee (MUST-REC) was used and it approved the research. Additionally, the committee approved an informed consent document which was used to get consent from the respondents before collection of the data. The next step was to get clearance from the Uganda National Council for Science and Technology (UNCST), the body which supervises research activities in Uganda. The proposal was submitted to UNCST and the study was cleared to be carried out. Before going to the field for data collection, the researchers paid a preinterview visit to all the respondents and made interview appointments with them. During the visit the researchers explained to the respondents the intentions and the duration of the interviews, which helped the respondents to set convenient dates and time. All respondents were met at their workplaces which made it possible for some to refer to important documents they had in their offices. Not to miss out on important data during interviews, the researchers sought the consent of the respondents to allow them have their responses recorded during the interview sessions. All the data gathered were subjected to content analysis in order to abstract relevant information. This was done by first transcribing all the interview responses, interpreting, reflecting and discussing them with fellow researchers after every session in the field to identify major themes and put them in categories.

\section{Findings}

The respondents were invited to respond to interview questions regarding how to improve TVET graduates transition to the world of work. Their responses are summarized below:

\subsection{Summary of Responses to Interview Questions}

During interviews with officials from the BTVET department, several pointed out that it is necessary to invite experienced personnel from industry to the TVET institutions as guest lecturers or facilitators of learning.

One of them said;

The involvement of experienced personnel from industry has several advantages. They bring with them the technical expertise and exposure. For example, they can get for learners places for industrial attachment, recommend the skilled ones for employment and lobby for sponsorship packages from multilateral companies for the financially disadvantaged learners (INT. BTVET, 14/08/2018).

To underscore the importance of this, one of the graduates in formal employment noted that;

The industrial training I underwent when I joined this company was really important for me. I worked so hard with colleagues and supervisors and I acquired a lot of skills which I could not have learnt at college training workshop. When I completed my programme at college, I came back and requested the manager for employment. He requested for my supervisor's recommendation. It was positive and that is how I got this job (INT. GFE. 1, 16/08/2018).

Responses to open ended items on questionnaires from some of the employers also emphasized the importance of industrial training, several noted that;

The young graduates should always apply early to be considered for industrial training places. Each year competition for places gets stiffer because the number of applicants keeps increasing. It's easy for us to absorb those who train with us in case we have vacancies since they know our work procedures (RES. EMPLOYER, 15/08/2018).

But industrial attachment isn't a bed of roses, as several respondents had different opinions. A graduate in formal employment recalled;

When I was still at college, I went to an organization to request for a vacancy as an intern to do industrial training. They manager agreed to offer me a place but on condition that I pay for the training. His argument was that since I pay tuition for training to my college, I should also pay for the 
company's training. I had no money to pay, so had to look for another place (INT. GFE. 2, 16/08/2018).

An official at the skilling Uganda secretariat highlighted the problem;

There is a low level of industrialization in the country. Most of our industries are small scale operators. They lack the latest technology. Even if we take our lecturers for refresher courses and students for industrial attachments, I don't think they will acquire the necessary expertise. However, on a positive note, the government is aggressively convincing foreign multilateral companies to come and invest here and many are responding positively. So, there is hope for the future (INT. SUS, 17/08/2018).

On a positive note, one official from BTVET department, at the ministry of education said:

The issue of improving quality of graduates from TVET institutions is among the priority issues on the government and our development pattern's agenda. For instance, currently through our pattern the African Development Bank $(A f D B)$, we have the support to Higher Education, Science and Technology (HEST) project at the ministry of education and sports. The five year project aims at contributing to Uganda's human capital skills development capacity building, particularly in education, science and technology to respond to labor market demands and spur productivity nationally. The HEST project objective is to improve equitable access, quality and relevance of skills training and research leading to job creation and self-employment. With this project, we expect a significant improvement in the quality of graduates in the coming years and easy transition to self-employment (INT. BTVET, 14/08/2018).

Most officials at the Ministry of Education and Sports, in the BTVET department advocated for institutional-industrial linkages as a means to facilitate graduate transition to the world of work.

One of them said:

TVET Institutions have to know that their products have to go to industry after they complete their programmes of study. However, I think there is a poor relationship between the institutions and industry. For instance, how often do they visit each other? In my view, TVET institutions should visit industries which employ their graduates from time to time and find out the activities taking place there. They can share ideas and talk about new emerging production process, skills requirements, and customer requirements and so on. This will help them align their training to suit the skills requirements of industry. Additionally, the institutions can request to have their lecturers and students attend re-fresher courses. I'm sure this can help in the transition of the TVET graduates to the world of work (INT. BTVET, 14/08/2018).

A trainer at a TVET institution, in response to an open ended item on questionnaires advised;

We try our best to equip our students with the necessary skills for gainful employment. But it's important to know that the population has increased leading to competition for the few available employment opportunities in our country. In my view, I would advise our young graduates to consider getting employment from abroad especially the Middle East through employment agencies. I would also advise them to lobby for opportunities as volunteers in companies. I would also advise them to do voluntary work. When one does voluntary work, he/she improves on the skills and it's easy for the company to absorb him/her (RES. TRAINER, 20/08/2018).

An official at the Ministry of Education and sports suggested Income Generating Units (IGUs) as another way of facilitating TVET graduates transition to the world of work. He said;

We at the ministry have always advised TVET institutions to turn their training workshops into vibrant Income Generating Units (IGUs). It offers the institutions and their students a lot of benefits. I remember when I was a student at former Uganda Polytechnic Kyambogo, now Kyambogo University in the late $90 \mathrm{~s}$, the mechanical and production engineering workshops received a lot of work from the industrial areas in and outside Kampala. The technicians in the workshops would engage me and my colleagues to help them complete the work on time. We would get paid for our input but most importantly, we learnt how to negotiate with the customers, improved our technical skills, and a good number of our colleagues were recommended for employment in the customers' organizations. I was told recently that such units were closed. Why close them? He wondered (INT. BTVET, 14/08/2018).

One of the officials at the employment secretariat suggested internship programs for graduates while waiting for employment. He said;

TVET is a skills based type of education. After college, if one sits idle at home for a long time, he/she can easily forget the skills acquired. Am of the view that, if government requests companies to offer internship opportunities to graduates, the companies would comply. This arrangement would make the graduates active, and eventually the best performers can easily be retained for gainful employment' (INT. ES. 1, 18/08/2018).

Another way to facilitate graduates' transition to the world of work was suggested by an official at the employment secretariat. She said;

TVET institutions should align their training to production the way it's done in the informal sectors. In the informal sectors, training is done alongside working and every day we see their products displayed for sale on highways and in trading centres. Every time I move around, I see fabricated window and door frames, agro-processing machines, beds, sofa sets and many more. Where are those from TVET institutions? Why don't we see products made from TVET institutions in display shops? In my view, this would be a very good way to prepare TVET graduates for self-employment. She concluded (INT. ES. 2, 18/08/2018).

During the interviews, some graduates in formal employment recalled how they got their jobs. One of them said;

The industrial training I underwent when I joined this company was really important for me. I worked so hard with colleagues and supervisors and I acquired a lot of skills 
which I could not have learnt at college training workshop. When I completed my programme at college, I came back and requested the manager for employment. He requested for my supervisor's recommendation. It was positive and that is how I got this job (INT. GFE. 3, 16/08/2018).

Another had this to say;

The company wrote to our institution requesting for finalists they could employ. I was lucky; my name was among those submitted. After a few weeks, they invited me for training. The training took four months, after which five of us were selected out and invited to negotiate contracts with the company. That is how I got employed here (INT. GFE. 4, 16/08/2018).

Another TVET graduate had this to say regarding transition;

The process of getting employment after college is not an easy one. I could see very many advertisements requiring my automotive qualifications and I submitted my applications but never got shortlisted. I kept wondering if I would ever get my chance. I knew I was skilled after the two years of training and industrial attachment experience. I had an idea to start a motor vehicle repair work shop but lacked money to hire premises and for acquiring tools. My chance came one day when my former class mate recommended me to join where he was working. Can't TVET institutions request government to avail some little capital and tools for graduates? He questioned (INT. GFE. 5, 16/08/2018).

\subsection{Summary of the Ways Identified for Facilitating TVET Graduates'Transition to the World of Work}

The different ways identified by the stakeholders for facilitating TVET graduates' transition to the world of work are summarized in table 1.

Table 1. Summary of ways identified for facilitating TVET graduates 'transition to the world of work.

\begin{tabular}{|c|c|c|}
\hline S/No. & Respondents & Ways identified \\
\hline 1. & Employers & 1. Industrial attachments \\
\hline 2. & TVET Trainers & $\begin{array}{l}\text { 1. Use employment agencies to connect the graduates to vacancies outside Uganda } \\
\text { 2. Volunteering in companies to acquire more skills, later they can be absorbed in employment. }\end{array}$ \\
\hline 3. & $\begin{array}{l}\text { Officials from the Ministry of } \\
\text { Education }\end{array}$ & $\begin{array}{l}\text { 1. Vibrant Income Generating Units (IGUs) at the institutions to introduce trainees to the world of work } \\
\text { 2. Institutional-industrial linkages } \\
\text { 3. Cooperation with development patterns to build capacity for self-employment in TVET institutions }\end{array}$ \\
\hline 4. & $\begin{array}{l}\text { TVET graduates in formal } \\
\text { employment }\end{array}$ & $\begin{array}{l}\text { 1. Start-up capital for self-employment } \\
\text { 2. Provision of tools and materials for self-employment }\end{array}$ \\
\hline 5. & Officials from the employers' union & $\begin{array}{l}\text { 1. Training with production } \\
\text { 2. Internship programs for graduates while waiting for employment. }\end{array}$ \\
\hline
\end{tabular}

\section{Discussion}

The various ways identified for facilitating TVET graduates' transition from training institutions to the world of work are discussed below;

Industrial attachments: Findings from the interviews identified industrial attachments as a way for TVET graduates to transition to the world of work. According to Kiplagat, Khamasi and Karei, the industrial attachment programme is vital to students because it introduces them to unfamiliar technology, work place expectations, work schedule, and the organizational structure of companies [31]. It makes students appreciate the real world of work, practice what they learnt in theory at college and improve their communication skills [32]. However, from the researchers' experience in TVET training institutions, it is very hard for trainees to secure industrial placements because of the large number of applicants. This prompted a colleague in TVET to advice;

...students and universities should consider going/ seeking for placements in SMEs (Small and Medium Enterprises) and local governments, including restaurants, small businesses start-ups, supermarkets, churches, markets, schools, county headquarters, etc. and avoid the temptation to only apply to go to big companies and offices where in most cases, they do not get a chance to be in the lead of showing the practical application of the things they have studied at universities and demonstrate the relevance of our education to the real needs of our people at the lowest levels. It pains me seeing university students on internship turned into office messengers and sent to carry chairs at meetings- and given little or no chance to apply what they are studying, simply because they want to be around Kampala at big corporations [33].

Employment agencies: Findings from the interviews further identified the use of employment agencies to connect TVET graduates to vacancies internally and abroad as another way for TVET graduates to transition to the world of work. A good example of the use of this model is in Canada, through the Canada-Saskatchewan Career and Employment Services (CSCES). In this model;

'Job seekers engage in strength-based, solution focused services intended to assist transition to employment and maximum self-sufficiency. Services target individuals receiving Employment Insurance (EI), which is a social program managed through the government of Canada; social assistance or the transitional employment allowance, both of which are provincially-managed income support programs. The programs and services offered through CSCES provide work readiness training, life skills, employment supports and work experience through partnerships with community-based organizations, municipalities and employers' [34].

In the view of the researcher, such an employment agency can be created in Uganda to avail similar services as those of CSCES to TVET graduates as a way to facilitate their 
transition to the world of work.

Income Generating Units (IGUs): Further, results from interviews revealed that another way to ease graduates transition to the world of work was through vibrant Income Generating Units (IGUs) at the institutions. In most TVET institutions, IGUs are created to lessen financial problems in these institutions due to inadequate funding from governments [35]. The IGUs in most institutions in Africa are of two groups; teaching (parallel degree) programs and nonteaching income generating activities [36]. In the view of the researcher, this can take the form of non-teaching income generating activities in the TVET institutions' training workshops. Trainees work side by side with the lecturers and technicians on jobs from outside the institution. As work is going on, the customers take note of the skilled trainees and later, trust them with their work or recommend them for employment in their enterprises.

Institutional-industrial linkages: Findings from the interviews identified institutional-industrial linkages as another way for TVET graduates to transition to the world of work. Several scholars have advocated for this approach. In Kenya, findings from Koech report of the commission of inquiry into the education system of (1999), argued that if TVET institutions are closely linked to the world of work, it's possible for them to solicit support to enhance practical training at the institutions through donations of equipment and tools, staff exchange programs and placement of students and staff on industrial attachment [37]. To further emphasize that point, Raihan argued that the fundamental purpose for TVET institutions to have links with industry is to understand each other's needs and how industry programs can address these needs. He further illustrated below the various ways in which TVET institutions and industry can collaborate. Through the traineeship and internship programs as indicated, it's easy for the trainees to be absorbed into employment as was the case with one of the respondents [38].

However, a major challenge for this kind of arrangement was observed in Bhutan. The government focus report of (2015) on TVET and labour market dynamics by the ministry of labour and human resource indicated that industries were not aware and did not understand various TVET programs [39]. In the view of the researchers, a similar scenario is common in many industrial set-ups in Uganda. However, it's easy to solve by having the training providers taking the initiative to visit and sensitize the industries.

Self-employment: Another of the ways identified was cooperation with development patterns to build capacity for self-employment in TVET institutions. This is line with a UNESCO-UNEVOC organized virtual conference of 2013, where invited participants on the UNEVOC e-Forum argued that;

'TVET institutions should strengthen links, not only with private sector employers, but also with a wider set of partners, including parents, community groups and youth groups, and that these groups should be involved in TVET design and implementation. E-Forum members further recognized that TVET institutions can play a role in creating jobs by offering entrepreneurship education to encourage and support self-employment. And also, TVET institutions take the initiative to build local, national and international partnerships to promote work opportunities for students' [40].

Start-up capital: Another finding from the interviews advocated for offering start-up capital to TVET graduates for self-employment as another way for TVET graduates to transition to the world of work. In his study about how do young people seek self-employment in Rwanda, Biseruka observed that the labour market is tight and self-employment encompasses various practices of informal orientation and self-directed learning experiences. The results revealed that TVET graduates experience a number of challenges such as lack of motivation, low confidence and experience, and lack of financial support to engage in self-employment activities [41]. In the view of the researchers, the idea of provision of start-up capital is good but the TVET graduates have to first undergo rigorous entrepreneurship training. There can also be issues with the implementation process. For instance, how to fairly recruit the graduates to benefit from the scheme? How much to offer? And which trades to benefit since TVET is diverse.

Provision of tools and materials to improve skills for selfemployment: Another finding from the interviews was to provide tools and materials to improve skills for selfemployment. The initiative is already being thought of in Uganda. As reported by Agaba, the government of Uganda through the Ministry of Education and Sports (MoES) is set to establish a Skills Development Fund (SDF) to enhance skills training and provide start up packages, especially for vulnerable students who have completed technical education but find it difficult to start own projects. Through the fund, more equipment, tools and machines will be purchased and given to technical institutions to enable more students join and have hands-on-skills. The move is meant to enable TVET to deliver skills required by the world of work. This was revealed by the ministry permanent secretary, Alex Kakooza during a feedback workshop with TVET institutions recently [42]. This is a strategy aimed at easing the school-to-work transitions of TVET graduates.

Training with production: Another finding from the interviews advocated for training with production at the institutions' training workshops. The initiative involves trainers setting real life projects as tasks and assignments for the trainees. After assessment, the projects are displayed in show rooms and sold to clients by the students. The initiative introduces the trainees to negotiation skills, customer care skills, marketing and networking skills among others. The initiative can also facilitate easy transition into selfemployment.

Internship programs: Findings from the interviews advocated for internship programs for graduates while waiting for employment as another way for TVET graduates to transition to the world of work. This approach is also supported by the World Bank. According to the 
World Bank, the most successful countries to adopt this approach are Germany and Japan through their 'dual system' model. The model combines part-time schooling with work and apprenticeship. The schools offer academic skills whereas the employers offer the formal training. This makes it easy for the employers to choose their future workers. But the model is not without challenges. The World Bank noted that it had failed to take off in developing countries because the modern wage sector in these countries has small shares of employment, there are no jobs for new apprentices and poor implementation of apprenticeships [8]. The notion of 'apprenticeships' was further supported by Adjei who noted that reforms in TVET to emphasize apprenticeships led to the success stories of the Asian and Pacific countries - the tigers and dragons [43]. In the view of the researchers, adopting this model in Uganda currently won't be feasible because of the same challenges identified by the World Bank. It's therefore better to concentrate on other strategies which may be applicable in the current economic state of Uganda.

\section{Conclusions}

Basing on the difficulty TVET graduates face in their transition from institutions to the world of work, it is important that stakeholders facilitate them through the following ways which were identified; industrial attachments, use of employment agencies, income generating units at the institutions, institutional-industrial linkages, self-employment, provision of start-up capital, provision of tools and materials for graduates to engage in self-employment, training with production and internship programs. The TVET graduates should be sensitized to embrace these approaches.

\section{Recommendations}

Basing on the findings of the study, it is recommended that:

a. a supportive policy framework to foster the cooperation of industry and training institutions be formulated because quality TVET depends on the collaboration of industry and training institutions.

b. an active labour market information system be established at TVET institutions to analyze, collect, evaluate and provide labour market information to identify evolving occupations, skills shortages and areas of skills oversupply and redundancy.

c. there should be an increase in apprenticeship programs arranged between the TVET institutions and industry to facilitate TVET graduates transition to the world of work.

d. TVET graduates with inadequate skills be recalled back to the training institutions to be supported through internship and other skills development programmes to increase their chances of securing employment.

e. TVET institutions adopt the following teaching approaches; case studies in the community, project- based learning, real life problem-based learning, teamwork learning activities, and trainee leadership improvement.

\section{Statement of Competing Interests}

The authors have no competing interests

\section{References}

[1] Rogers M. \& Creed P. (2000). School-to-Work Transition: From Theory to Practice, School of Applied Psychology. Griffith University - Gold Coast. Queensland, Australia 4217.

[2] Peila-Shuster J. J (2016). Supporting Student Transitions: Integrating Life Design, Career Construction, Happenstance, and Hope. South African Journal of Higher Education Volume 30,| Number 3, 2016 pages 54-67 eISSN 1753-5913 http://dx.doi.org/10.20853/30-3-633.

[3] Hrabowski, F. A. 2015. The future of work: Preparing students for a changing world of work. Pacific Standard. http://www.psmag.com/business-economics/the-future-ofwork-preparing-students-for-a-changing-world-of-work.

[4] Chong, Y. S., \& Ahmed, P. (2014). A phenomenology of university service quality experience: Uncovering the essence of meaning among business undergraduates in Malaysia. International Journal of Educational Management, 28, 36-52.

[5] World Development Report 2007: Development and the Next Generation. Washington, www.unevoc.unesco.org/publications

[6] EFA Global Monitoring Report (2012). Youth and Skills: Putting education to work UNESCO, 2012.

[7] Bai, B. \& Geng, X. (2014). Transferable skills in technical and vocational education and training (TVET): Policy and practice in China. www.tvet-online.asia Issue 3.

[8] World Bank, (2008). Transitions to Working Life for Africa's Youth: In Youth in Africa's Labor Market Ed. Garcia, M \& Fares, J, Chapter two. The International Bank for Reconstruction and Development / World Bank 1818 H Street NW Washington, DC 20433.

[9] Oviawe, J. I., Uwameiye, R., Uddin, P. S. O. (2017). Bridging Skill Gap to Meet Technical, Vocational Education and Training School-Workplace Collaboration in the 21st Century. International Journal of Vocational Education and Training Research. Vol. 3, No. 1, 2017, pp. 7-14. doi: 10.11648/j.ijvetr.20170301.12.

[10] Lee, J. (2009). Partnerships with industry for efficient and effective implementation of TVET. International Journal of Vocational Education and Training, 17 (2), 39-56.

[11] Atchoarena, D. \& Delluc, M. (2001). Revisiting Technical and Vocational Education in Sub-Saharan Africa: An update on trends, innovations and challenges. A Report for the International Institute for Educational Planning for the World Bank. Washington, D. C.: World Bank.

[12] Dasmani, A. (2011). Challenges facing technical institute graduates in practical skills acquisition in the Upper East Region of Ghana. Asia-Pacific Journal of Cooperative Education, 12 (2), 67-77. 
[13] GoU: The Business, Technical, Vocational Education and Training Act 2008.

[14] MoES (2011). Skilling Uganda, BTVET Strategic Plan 20112020. Kampala: Ministry of Education and Sports.

[15] Okinyal, H. (2012). Reforming the Business, Technical Vocational Education and Training (BTVET) sub-sector: Challenges, Opportunities and Prospects, A paper presented at the Uganda Vice Chancellors' Forum (UVCF), November 2012, Kampala, Uganda.

[16] MoFPED (2014) Uganda's Employment Challenge: An Evaluation of government's Strategy. Ministry of Finance, Planning and Economic Development, November 2014.

[17] Okello, B. (2011). The factors influencing the negative attitude towards Technical Vocational Education and Training (TVET) in the post-colonial Uganda, $\mathrm{PhD}$ thesis, Kenyatta University, Nairobi Kenya.

[18] Wood, J. C. M. (2008). The Impact of Globalization on Education Reform: A Case Study of Uganda. PhD thesis; University of Maryland, College Park, U.S.A.

[19] Nalumansi, S. R, Mula-maige, S., Oluka, S, Rosch, G, \& Moll D. (2003). Skilled manpower in Uganda: A study on the BTVET Report for European Union Ministry of Education and Sports.

[20] UNESCO. (2007). Technical education, policy framework, innovative practices and international partnership. China: UNESCO.

[21] Super, D. E. (1990). A life-span, life-space approach to career development. In D. Brown \& L. Brooks (Eds.), Career choice and development: Applying contemporary approaches to practice (2nd ed., pp. 197-261). San Francisco, CA: Jossey-Bass.

[22] Leung S. A. (2008). International Handbook of Career Guidance, J. A. Athanasou, R. Van Esbroeck (Eds.) Springer Science, Business Media B. V. The Chinese University of Hong Kong, Hong Kong SAR, China.

[23] Duchscher J. E. B. (2009) Transition shock: the initial stage of role adaptation for newly graduated Registered Nurses. Journal of Advanced Nursing 65 (5), 1103-1113. doi: $10.1111 / \mathrm{j} .1365-2648.2008 .04898$.

[24] Mashigo A. C. L. (2014). Factors Influencing Work Readiness of Graduates: An Exploratory Study. Master's Thesis Stellenbosch University.

[25] Wood L. N, Psaros J, French E. \& Lai J. W. M. (2015). Learning experiences for the transition to professional work, Cogent Business \& Management (2015), 2: 1042099. http://dx.doi.org/10.1080/23311975.2015.1042099

[26] Quintini G. and T. Manfredi (2009), "Going Separate Ways? School-To-Work Transition in The United States and Europe”, OECD Social, Employment and Migration Working Papers No. 90, OECD Publishing, Paris, http://dx.doi.org/10.1787/5jzbb2t1rcwc-en.

[27] OECD (2010), Learning for Jobs, OECD Reviews of Vocational Education and Training, OECD Publishing, Paris, http://dx.doi.org/10.1787/978926 4087460-en.

[28] Harvey, L., Locke, W. and Morey, A., 2002, Enhancing
Employability, Recognising Diversity: Making links between higher education and the world of work. London, Universities. http://www.universitiesuk.ac.uk/bookshop/downloads/employ ability.pdf

[29] Kombo, D. K, \& Tromp, D. L. A. (2006). Proposal and thesis writing. An introduction. Pauline publication, Nairobi.

[30] Cohen, L., \& Manion, L. (1994). Research Methods in Education. London: Routledge.

[31] Kiplagat H, Khamasi J. W, \& Karei R. (2016). Students' Experience of Industrial Attachment: A Case of a Public University Journal of African Studies in Educational Management and Leadership Vol: 7 No: 1, August 2016, 8297.

[32] Matamande W, Nyikahadzoi L, Taderera E. (2013). An investigation of the effectiveness of work related learning: A case of the industrial attachment program offered by the faculty of commerce, University of Zimbabwe. Ever - Journal of Instructional Pedagogies, 2013.

[33] Julius Mucunguzi, group whatsapp message 2018.

[34] Asia-Pacific Economic Cooperation (APEC) (2008). The Role of TVET Providers in Training for Employees. APEC Forum on Human Resources Development. $19^{\text {th }}-21^{\text {st }}$ November, Chiba-Japan.

[35] Murage S., M. \& Onyuma S., O. (2015). Analysis of Financial Performance of Income Generating Activities in Public Higher Learning Institutions: Experience from Egerton University, Kenya. Research journal of finance and accounting. Vol. 6 No. 7.

[36] Tsuma A., N. \& Mugambi M., F. (2014). Factors Influencing Performance of Income Generating Units in Public Universities. European Journal of Business and Management. Vol. 6, No. 10, 2014

[37] Government of Kenya (1999). Koech Commission Report and Recommendations - Koech Report. Nairobi, Kenya.

[38] Raihan, Dr. (2014). Collaboration between TVET Institutions and Industries in Bangladesh to Enhance Employability Skills. 2. 50-55. International Journal of Engineering and Technical Research (IJETR) ISSN: 2321-0869, Volume-2, Issue-10, October 2014.

[39] Government of Bhutan (2015). A focus on TVET \& Labour Market Dynamics the ministry of labour and human resource. Thimphu-Bhutan.

[40] UNESCO-UNEVOC (2014). Vocational pedagogy, what it is, why it matters and how to put it into practice. Report on the UNESCO-UNEVOC virtual conference: 12 to 26 May 2014, UNEVOC e-Forum. Bonn, German.

[41] Biseruka, D. (2010). How do Young People in Rwanda seek Self-Employment in a Tight Labour Market: A Case Study of GASABO District in Kigali-City. Erasmus University thesis repository.

[42] Agaba, V. (2017, June 05). Education ministry to establish skills fund. New Vision newspaper, Kampala, Uganda.

[43] Adjei, N. A. K. (2013). Evaluation of the Industrial Attachment Programme in Selected Ghanaian Public Polytechnics. PhD Thesis, University of Cape Coast. 